\title{
Biotic and abiotic connections on a granitic catena: Framework for multidisciplinary research
}

\begin{tabular}{|c|c|}
\hline \multicolumn{2}{|c|}{$\begin{array}{l}\text { Authors: } \\
\text { Beanelri B. Janecke }{ }^{1} \\
\text { Johan van Tol }{ }^{2} \\
\text { Izak P.J. Smit } \\
\text { Andri C. van Aardt } \\
\text { Edward S. Riddell } \\
\text { Maitland T. Seaman } \\
\text { Wijnand J. Swart } \\
\text { Pieter J. du Preez } \\
\text { Pieter A.L. le Roux }\end{array}$} \\
\hline \multicolumn{2}{|c|}{$\begin{array}{l}\text { Affiliations: } \\
{ }^{1} \text { Department of Animal, } \\
\text { Wildlife and Grassland } \\
\text { Sciences, Faculty of Natural } \\
\text { and Agricultural Sciences, } \\
\text { University of the Free State, } \\
\text { Bloemfontein, South Africa }\end{array}$} \\
\hline \multicolumn{2}{|c|}{$\begin{array}{l}{ }^{2} \text { Department of Soil, Crop } \\
\text { and Climate Sciences, Faculty } \\
\text { of Natural and Agricultural } \\
\text { Sciences, University of the } \\
\text { Free State, Bloemfontein, } \\
\text { South Africa }\end{array}$} \\
\hline \multicolumn{2}{|c|}{$\begin{array}{l}{ }^{3} \text { South African National Parks, } \\
\text { Scientific Services, Skukuza, } \\
\text { South Africa }\end{array}$} \\
\hline \multicolumn{2}{|c|}{$\begin{array}{l}{ }^{4} \text { Centre for African Ecology, } \\
\text { School of Animal, Plant and } \\
\text { Environmental Sciences, } \\
\text { University of the } \\
\text { Witwatersrand, } \\
\text { Johannesburg, South Africa }\end{array}$} \\
\hline \multicolumn{2}{|c|}{$\begin{array}{l}{ }^{5} \text { Department of Plant } \\
\text { Sciences, Faculty of Natural } \\
\text { and Agricultural Sciences, } \\
\text { University of the Free State, } \\
\text { Bloemfontein, South Africa }\end{array}$} \\
\hline \multicolumn{2}{|c|}{$\begin{array}{l}{ }^{6} \text { South African National Parks, } \\
\text { Conservation Management, } \\
\text { Skukuza, South Africa }\end{array}$} \\
\hline \multicolumn{2}{|c|}{$\begin{array}{l}{ }^{7} \text { Centre for Water Resourc } \\
\text { Research, University of } \\
\text { KwaZulu-Natal, } \\
\text { Pietermaritzburg, } \\
\text { South Africa }\end{array}$} \\
\hline \multicolumn{2}{|l|}{ Read online: } \\
\hline 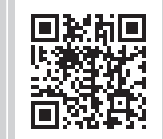 & $\begin{array}{l}\text { Scan this QR } \\
\text { code with your } \\
\text { smart phone or } \\
\text { mobile device } \\
\text { to read online. }\end{array}$ \\
\hline
\end{tabular}

Local environmental gradients on a catenal scale create ecological patterns from the crest to the stream of the hillslope. Bottom-up drivers interact with top-down controls to give rise to these patterns. A multidisciplinary project was conducted to study the processes that govern functioning, structure and heterogeneity on a catena in a third-order catchment in the Southern Granite Supersite in the Kruger National Park. The project included abiotic components (e.g. groundwater-surface water interactions, soil chemical and physical properties) as well as biotic components (e.g. soil microbes, small aquatic organisms in ephemeral pools, plant communities, vegetation structure and mammal diversity). Each of these components was investigated in detail along the catenal gradient and reported on in separate articles in this special issue. The drought of 2015-2016 occurred during the sampling period of the study and information on the response of vegetation and mammals to the drought were included. In this article, a synthesis of findings from the separate components or disciplines is provided to highlight the interactive functioning and ecological patterns of the catena. These findings were then used to develop a framework for multidisciplinary studies in similar environments. The framework highlights the interactive relationships between various components of the ecosystem and the importance of a multidisciplinary approach.

Conservation implications: The findings of this study were used to develop a conceptual framework outlining how a range of biotic and abiotic patterns and processes interact along the catenal gradient. The framework highlights the importance of recognising these interactions in a multidisciplinary approach focused on one supersite.

Keywords: Climate; Hydrology; Interdisciplinary studies; Mammals and mud wallows; Trophic levels.

\section{Introduction}

One of the key concepts linking ecology and biodiversity management is environmental heterogeneity. In the words of Pickett, Cadenasso and Benning (2003):

The general concept of heterogeneity becomes ecologically meaningful when it is given operational life by specifying what agents modify what substrates, what controls the modification, and what organisms or processes respond to the resulting spatial template. (p. 25)

The concept of savanna heterogeneity has been fundamental in how this has informed the management of the Kruger National Park (KNP), and has influenced, for example, how fire, artificial surface water and large herbivores are managed to maintain, mimic or, in some cases, restore inherent heterogeneity. For an overview of the concepts of heterogeneity in the savanna context on different levels from a fine to a broader scale, and how that has influenced thinking and management of the KNP, see Du Toit, Rogers and Biggs (ed. 2003) and Rogers (2003). 'Heterogeneity' is a broad term, but can comprise differences and interactions between soil types and properties, vegetation composition and structure, patchiness and patterns, sub-habitats, animal presence and so on.

${ }^{8}$ Centre for Environmental Management, Faculty of Natural and Agricultural Sciences, University of the Free State, Bloemfontein, South Africa

${ }^{9}$ Digital Soils Africa, South Africa

${ }^{10}$ Previously Institute for Groundwater Studies, Faculty of Natural and Agricultural Sciences, University of the Free State, Bloemfontein, South Africa

Corresponding author: Beanelri B. Janecke, janeckbb@ufs.ac.za

Dates: Received: 01 Oct. 2019 | Accepted: 17 Apr. 2020 | Published: 29 Oct. 2020

How to cite this article: Janecke, B.B., Van Tol, J., Smit, I.P.J., Van Aardt, A.C., Riddell, E.S., Seaman, M.T. et al., 2020, 'Biotic and abiotic connections on a granitic catena: Framework for multidisciplinary research', Koedoe 62(2), a1600. https://doi.org/10.4102/koedoe. v62i2.1600

Copyright: ( 2020 . The Authors. Licensee: AOSIS. This work is licensed under the Creative Commons Attribution License.

Note: Special Issue: Connections between abiotic and biotic components of a granite catena ecosystem in Kruger National Park, sub-edited by Beanelri Janecke and Johan van Tol.

$\uparrow, 1960-2019$. 
At the scale of our study (in this instance, a third-order catchment in a granitic landscape), heterogeneity is the outcome of local environmental gradients along a hillslope (from the crest to the valley bottom). This spatial heterogeneity typically exhibits a common form of organisation and symmetry - termed the catena (chain) concept. The term was originally used by Milne (1936) to describe the soil distribution patterns in East Africa, but can be expanded to include processes causing differentiation along the hillslope and processes causing vertical differentiation in ecological properties. Although the patterns are normally associated with gradients (e.g. gradual increase in moisture downslope), it can also include sharp transitions caused by geology and geological features (e.g. seepline and alluvial deposits).

Bottom-up drivers (like climate and soils), together with topdown controls (like fire and herbivory), interact to give rise to the emergent heterogeneity and patterning. This is illustrated in the article by Sankaran et al. (2005), where mean annual precipitation (bottom-up environmental gradient) influences the upper asymptote of tree cover, whilst top-down disturbance factors (like fire and herbivory) and other bottom-up factors (i.e. soil and climate) explain the large variability observed under the asymptote. Soils interact with biology, the soil is a habitat for the biota and the biota is controlled by the macroand microclimate above ground and water and nutrient supply from below ground. These relationships between environmental controls create soil distribution patterns with specific characteristics (e.g. hydrological, structural and chemical), which partly act as abiotic templates determining the vegetation above ground on a catena. The resulting vegetation patterns provide heterogeneity in terms of food and habitat for a range of animals (e.g. from open grassy areas for grazers to dense wooded areas for browsers and including everything in between) (Smit \& Prins 2015). This model of the biodiversity-heterogeneity nexus rests on ideas about the nature of the ecological community, species assemblage processes and niche construction. Whilst savanna science has generated a broad conceptual framework of the hierarchy and processes of heterogeneity and its management in the KNP, there is still a need to improve our understanding of ecological patterns and interactions between different components of the ecosystem in granitic catenas.

With this as background, a multidisciplinary project was conducted that specifically focused on hydrology, soil, microbial, small aquatic organisms (in ephemeral pans and mud wallows), vegetation, mammal diversity and heterogeneity linked to below ground-above ground relationships along the catena or hillslope. Each of these different components of the ecosystem was researched separately and published as individual articles in a special issue, which this article (as part of the same special issue) aims to integrate. The objectives of this article were (1) to provide a framework of ecological patterns and interactions linking certain abiotic and biotic components of the catena ecosystem and (2) to briefly synthesise the main findings from the individual multidisciplinary research articles published in this special issue. A brief overview of the study area is provided together with a concise report of methodological approaches followed during the multidisciplinary project. Detailed descriptions of materials and methods can be found in the individual articles.

\section{Methods \\ Study area and surveys}

The study was conducted in KNP on the Southern Granite Supersite (Stevenson-Hamilton Supersite) (Smit et al. 2013). The supersite is considered a 'typical' granite ecosystem in southern KNP and has previously been identified as a focal site for multi-scaled and multi-disciplinary research to understand abiotic and biotic patterns and processes of these granitic landscapes (Smit 2020). The project focused on one specific catena of a third-order catchment between $25^{\circ} 06^{\prime} 28.6 \mathrm{~S}, 31^{\circ} 34^{\prime} 41.9 \mathrm{E}$ and $25^{\circ} 06^{\prime} 25.7 \mathrm{~S}, 31^{\circ} 34^{\prime} 33.7 \mathrm{E}$ near Skukuza. This catchment eventually drains into the perennial Sabie River further to the north.

The multidisciplinary project continued on earlier work conducted by Riddell et al. (2014) focusing on groundwatersurface water interactions and included the same catena as part of the third-order catchment. The catena is approximately $500 \mathrm{~m}$ from top (crest) to bottom (drainage line) with four hydrometric monitoring stations that recorded soil matric potential at different depths (Riddell et al. 2014; Riddell et al. 2020). A hydropedological survey was conducted along the belt transect, from crest to drainage line, which included 49 soil observations (10 m intervals). The hydropedological survey included detailed morphological description and classification of the soils as well as in situ measuring of hydraulic properties. This was supplemented with sampling for laboratory determination of physical and chemical properties of the soils. Soil information was used to derive a conceptual model of hillslope hydrological response (Bouwer, Le Roux \& Van Tol 2020).

Plants were classified based on species composition and abundance and grouped into communities for the same 49 plots in the belt transect where the soil observations were made (Theron, Van Aardt \& Du Preez 2020). Vegetation composition and structure were also determined (Janecke 2020), as well as wildlife habitat and mammal species presence that were noted through camera trapping (Janecke \& Bolton 2020). Temporary surface water sources (i.e. small ephemeral pans, animal-created wallows and other vernal pools) sustained by hillslope interflow were sampled for small aquatic organisms and their resting stages, while soil samples were taken of mud in depressions, of soils in the belt transect on the catena, and of soil associated with plant roots. Next-generation sequencing and isolations were used to explore potential differences in fungal (Gryzenhout et al. 2020) and bacterial communities (Vermeulen, Cason \& Swart 2020) in the rhizosperes (root area) across different catenal positions with different resulting soil chemical compositions. 
Extreme drought conditions coincided with the study period during one of the strongest El Niño southern oscillations in the historical record ( $\mathrm{Hu} \&$ Fedorov 2017; Malherbe et al. 2020; Swemmer et al. 2018). The impacts of this drought started during late 2014 when rainfall at the nearest rainfall station (Skukuza; approximately $13 \mathrm{~km}$ north of study site) for the 2014-2015 rainfall season was $350.4 \mathrm{~mm}(63.7 \%$ of long-term average). It became severe from 2016 onwards when total rainfall was very low during the 2015-2016 rainfall season (194.2 mm, 35.3\% of long-term average) (SANParks unpublished weather data). In March 2016, after a big rainfall event in the midst of the drought, some soil, mud and water samples were taken. During October 2016, barely any herbaceous vegetation remained and there was no standing water at the study site. Herbaceous vegetation cover, plant species composition and large animal presence (on a species basis) were, however, still recorded annually from 2015 to 2017 (Janecke 2020, Janecke \& Bolton 2020, Theron et al. 2020). Although the drought did present challenges in terms of achievement of our original objectives, it also created an opportunity to study such an event, with a general paucity in drought-related studies in savannas (i.e. Smit \& Bond 2020, Theron et al. 2020). As such, an opportunity arose to study how the vegetation on the catena would recover after the drought (Van Aardt et al. 2020). The vegetation at the study site was therefore surveyed in the growing seasons of 2015 (beginning of drought) to 2018 (post-drought).

\section{Developing the framework of interconnectivity}

The framework to highlight the interconnectivity between the various components of this ecosystem was developed through several discussions and workshops between the various researchers. Where available, the literature on similar studies was consulted to identify relationships between various components. Although some of the main components of ecosystem connectivity were addressed in this study, the framework also identified other relationships which should be addressed in future research.

\section{Conceptual framework of interconnectivity of the catena ecosystem}

A catena is a soil sequence where each soil group occurs on similar parent material, but in arrays from the crest to the footslope along a hillslope (Brady \& Weil 2002). Differences in elevation and in water flow patterns can lead to the transport of dissolved (i.e. salts) and suspended substances from higher- to lower-lying areas. At the midslope (localised) and/or footslope of these catenas, a clay layer occurs as a less permeable barrier that significantly retards flow, where water seeps through the saprolite on the surface which evaporates after some time - these areas are called 'seeps' or 'seep zones'. Downslope of the seeps, sodium accumulates to create sodic areas if rainfall is not sufficient to cause leaching of the accumulated salts (Brady \& Weil 2002; Khomo \& Rogers 2005).
The southern granites of KNP can have well, moderately or poorly drained soil forms. The spatial distribution is dominantly associated with terrain morphology and depends on a combination of soil forming factors (e.g. parent material and topography). All of this results in varying types of fertility along the catena that forms different gradients of supply to the soil biota. The heterogeneity in soil fulfils different hydrological functions. Firstly, it controls infiltration rate that determines runoff. Secondly, it controls plant waterholding capacity. Thirdly, it regulates sub-surface lateral water flow in sandy crests with low clay content. Fourthly, it serves as a clay plug and creates surface water flow in clayey areas down the slope where permeability of soil restricts drainage and infiltration (Khomo et al. 2011). These effects of soil texture, soil moisture and soil water-holding capacity are expressed in distribution and composition of vegetation along a catena (Theron et al. 2020).

The catena thus forms an ecosystem that consists of abiotic (gradient of soil types, soil properties and nutrients; ground water flow; surface water; topography; micro-climate; etc.) and biotic components (micro-organisms, plants and animals) that are connected and interact in the different zones present along the hillslope. The focus of this section is to describe the interconnectivity between some of the components of the catena ecosystem that formed part of a multidisciplinary study conducted on one catena or hillslope. This article summarises only the basic connections between soil, hydrology, micro-organisms in the rhizosphere and roots of dominant vegetation, vegetation structure, mammals, permanent and temporary water sources, and drought in the catena ecosystem. The readers are referred to the specific articles in the special issue for further detail.

Figure 1 shows a simplified overview of how the abiotic and biotic components that formed part of this study are interlinked. Other important taxa (e.g. detritus feeders, decomposers, birds, reptiles, etc.) and processes (e.g. fire) that did not form part of the study, but are deemed critical in the Savanna Biome, were included using dotted line blocks in Figure 1. Note, however, that no connections between these taxa and other components were indicated as it falls beyond the scope of what was studied here (Figure 1). No fire went through the study area during the time of this study and the mean fire return interval is 5.8 years for the area (Smit et al. 2013). The impact of elephants is also included in the discussion, but not indicated separately in the figure as it is implicitly part of the 'herbivores' and 'mammals' components. Some of the ecosystem components have been lumped together in Figure 2 to illustrate the interconnectivity in more detail (i.e. Figure 1 focuses on ecosystem components in some detail, whilst Figure 2 highlights ecosystem connections).

The following discussion refers to the numbered arrows in Figure 2 - the arrows represent relationships between the various ecosystem components covered in this study. Climate is one of the key drivers of patterns, processes and heterogeneity. Climate, which includes inter alia precipitation (volume and intensity), temperature, radiation and humidity, determines 


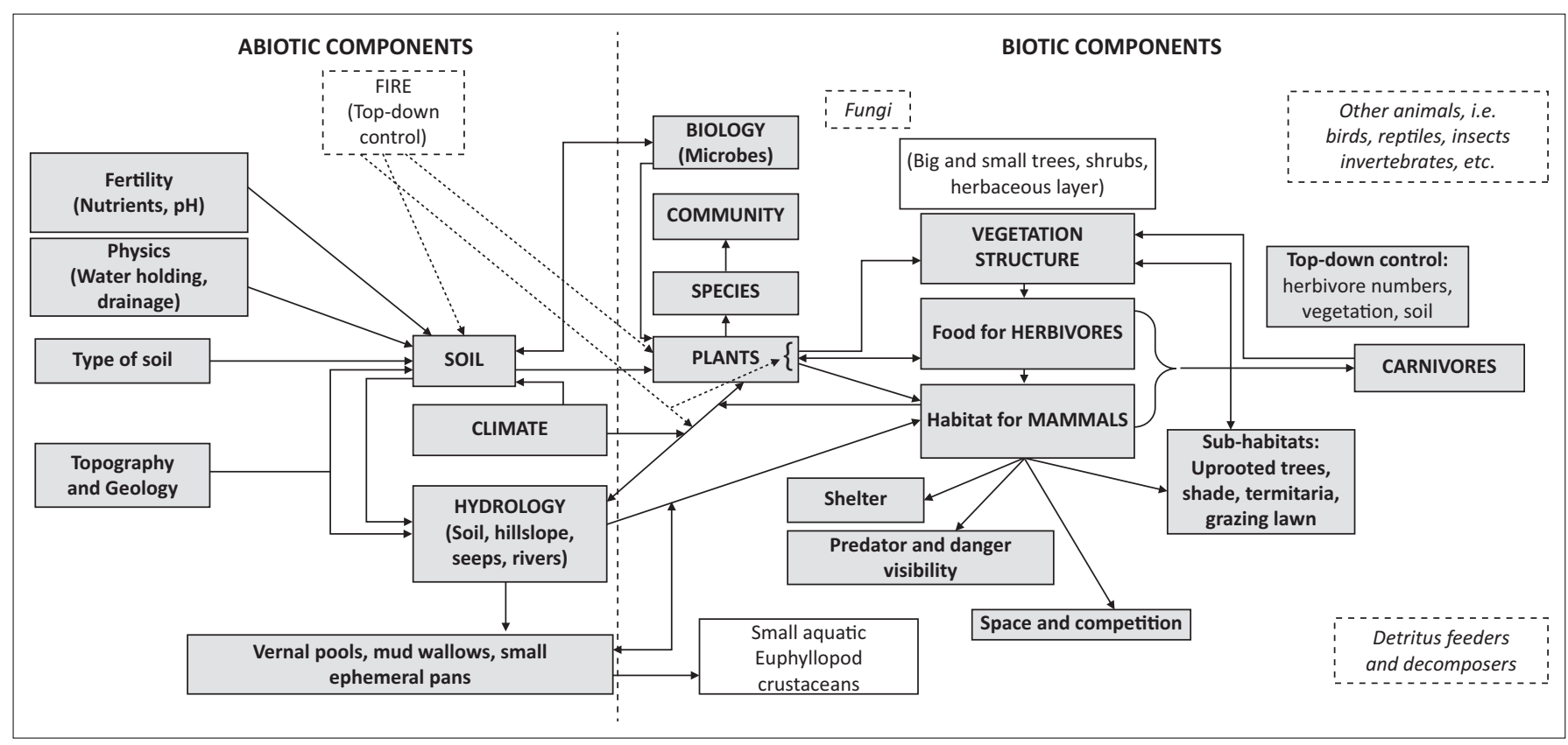

FIGURE 1: Links between abiotic and biotic components of the savanna granitic catena ecosystem. Ecosystem components that did not form part of this study are indicated in dotted line blocks, but only fire has been linked to other components. A connection to soil or plants implies its sub-components as well.

hydrological processes (1), as well as soil properties (10), micro-organism activity (they may become dormant during dry conditions) (11), vegetation types (19), presence of mammals (20) and standing water in the temporary mud wallows and vernal, ephemeral pools (15).

Soil is a first-order control of hydrological processes as it governs infiltration rates, storage and drainage (2). The relationship between soil and hydrological processes is, however, interactive, as water plays a primary role in the formation of the morphological, chemical and biological properties of soil (2). These interactions between soil and water are known as hydropedology. The soil distribution pattern is determined by five soil-forming factors of which geology and topography are key factors at the hillslope scale (3). In combination with the soil distribution, the topography affects hydrological processes (4).

Nutrients, water and anchorage are key provisioning functions of soils to plants (5). Different soils have specific abilities to support plant species and vitality of growth; thus, the soil distribution pattern is a key determinant in the distribution of various vegetation communities at catenal or hillslope scale. Plants, on the contrary, influence soil processes like infiltration and provide soil with organic material and nutrients through their leaves and root systems. Mining of nutrients from the subsoil and fractured rock is an important biocycling process that brings nutrients from deep soil layers and returns it to the surface, which determines the chemical, physical and biological properties of soil. In combination with the soil distribution pattern (as impacted by topography, geology and hydrology), micro-climate and microtopography can influence soil water availability that governs vegetation distribution in savannas (5).
The patchiness of the vegetation is a common occurrence in savannas and is observed at specific scales. Vegetation are grouped in patterns because of species composition and plant communities growing in the same local patch, presence of bare and vegetated patches, sub-canopied habitats that differ from open uncanopied areas, varying vegetation structure, etc. Spatial patterns can be described based on the size of plants and their canopies (vegetation structure), as an example. Sub-canopy shaded habitats are not only important for thermal regulation of animals, but also are preferred areas of grazing (Figure 2, number 7) because large woody plants change the availability of resources to the herbaceous layer by mostly creating patches of higher nutrition and moisture under the canopies of especially large trees (Treydte et al. 2011).

Large trees $(>5 \mathrm{~m})$ are important in the environment, but declines in their numbers have been reported in KNP (Eckhardt, Van Wilgen \& Biggs 2000). Density of large trees on granites has decreased by 15\% between 1984 and 1996 (Whyte, Van Aarde \& Pimm 2003). Whyte et al. (2003) described a change in the structural diversity (but not in woody species diversity) in which woody vegetation was converted to a short woodland (with higher density of small trees and shrubs), because of a declining density of large trees. According to Trollope et al. (1988) and Whyte et al. (2003), elephants were primarily responsible for killing trees larger than $3 \mathrm{~m}$ and large tree recruitment was prevented by increase in frequency of fires. In the Nkuhlu exclosures (also on a granite catena but next to the perennial Sabie River) where herbivores are excluded through fences, the density and number of big trees are higher (Siebert \& Eckardt 2008). The proximity to the river may also play a role in the presence of big trees because of higher probability of sub-surface water. Using aerial Light Detection and Ranging (LiDAR) 


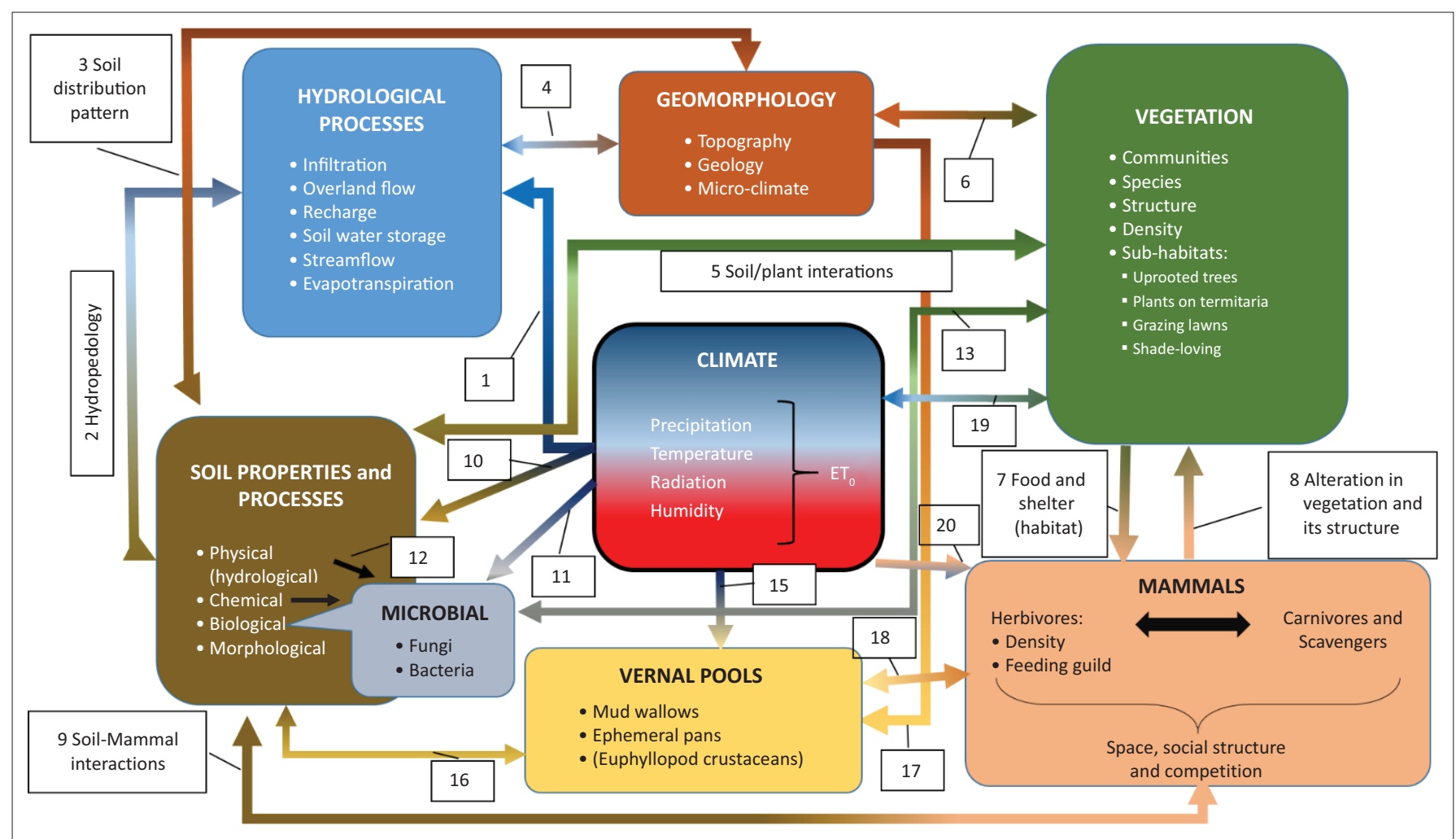

$\mathrm{ET}_{0}$, evapotranspiration.

FIGURE 2: Interconnectivity of components that formed part of this study on a granitic catena ecosystem in the savanna.

collected over time, it was determined that the rate of treefall was sixfold higher in areas outside of herbivore exclosures where elephants had direct access, as compared to areas within the exclosures which was protected from elephants (Asner \& Levick 2012). This pattern seemingly also plays out over larger landscape scales (Asner et al. 2016).

Not only does vegetation influence herbivore spatio-temporal patterns, but herbivores also influence vegetation patterns. Number 8 in Figure 2 implies the impact of all mammalian herbivores (including grazers, browsers, mixed feeders and the mega-herbivores) on vegetation structure and species composition. The impact of herbivores on vegetation composition and structure is not restricted to woody vegetation as described above. Increased and frequent grazing of the herbaceous layer often result in changing grass species composition and structure (i.e. from tall bunch grasses to short stoloniferous grazing lawns; Grant et al. 2019; Hempson et al. 2015). The variation in spatial distribution of quality and quantity of forage contributes to the different ways that various large herbivores feed at a local scale. The density of animals, social structure, animal behaviour, palatability of plants, competition and forage regrowth patterns may also play a role. Grazing that varies spatially can potentially limit the expression of vegetation distribution patterns that are related to edaphic factors that operate at larger scales (Adler, Raff \& Lauenroth 2001; Augustine 2003).

The relationship between vegetation and mammals is also interactive (7 and 8, Figure 2): vegetation (plant species, palatability and abundance) is not only the source of food for herbivores, but also limits their numbers (plant defence mechanisms, availability of food - bottom-up control), which will determine the occurrence and behaviour of animals on different areas on the catena (7). Herbivores can stimulate plant growth through pruning or inhibit growth through overutilisation (i.e. McNaughton 1983; Milewski \& Madden 2006). Vegetation also provides shelter against elements and against predators, or it can increase predation risk (limited visibility). The strategy of some animals, such as bushbuck, is probably to 'hide' from predators in dense undergrowth, whereas other species like wildebeest prefer open areas to see predators. Vegetation thus plays an important role when considering the landscape of fear created by the possible presence of predators in a denser area with lower visibility (i.e. Laundre, Hernandez \& Ripple 2010; Nasar \& Jones 1997). As the vegetation (as food and habitat) would impact the occurrence and abundance of herbivores, it is likely that it would also impact the occurrence of carnivores that feed on the former. The presence of carnivores can have a top-down effect on the ecosystem (Figure 1) and thus can impact the assemblage structure and space-use patterns of herbivores in an area (through creating landscapes of fear in areas that are mostly avoided by herbivores versus areas with good visibility frequented by herbivores) (e.g. Le Roux, Kerley \& Cromsigt 2018). Herbivores feed on and interact with the vegetation and impact the soil (9) (through trampling, nutrient enrichment through dung, digging holes and causing erosion through intense utilisation of vegetation); therefore, lower herbivore numbers (regulated top-down by carnivores), or changed space-use patterns (e.g. herbivores 
aggregating in open areas at night to reduce predation risk Burkepile et al. 2013), can have cascading effects on vegetation and soil. Large herbivores (especially elephants) can have a direct impact on the vegetation structure (e.g. uproot trees) and aid in creating micro-habitats (Augustine 2003) underneath fallen trees or scattered branches left behind after feeding (8).

Uprooting of trees by elephants would also impact the soil properties (9, Figure 2) through changing the physical properties of soil (e.g. decrease bulk density, increase infiltration rates and bring rocks up to the topsoil). Herds of elephant and rhino could result in soil compaction, whilst hoofed animals can often break soil crusting and therefore actually loosen soil. These animals can also provide valuable nutrients in the form of excretions and decomposing carcasses. Soil further provides a habitat for soil organisms and a substrate for plants to grow in as food source for smaller animals (mice, moles, hares, etc.), whilst the animals, in turn, increase macro-porosity of the soils through tunnelling (9) (these processes were not specifically researched in the current study).

Spatial patterns consisting of vegetated patches that alternate with bare soil areas are characteristic in savannas (Augustine 2003; Rietkerk et al. 2000). These patches can vary greatly in size and can be attributed to interactions between biotic (trampling, bulk and selective grazing, animal densities, competition, seed dispersal, etc.) and abiotic factors (variation in topography, surface water runoff, soil types and depth, soil properties, rainfall patterns that vary, microclimate, etc.) (Augustine 2003). Sodic patches are another example of large open areas that are more sparsely vegetated than surrounding areas on the catena. Khomo and Rogers (2005) used evapotranspiration models for upland-based catena and riparian-based areas to predict vegetation zonation and found that zonation of catena vegetation is dictated by a gradient in salt tolerance, whilst an increase in the surface area of the sodic patch is evident over time as a result of this progressive salt accumulation. Rietkerk et al. (1997) described a model where a feedback occurs between vegetation cover and water infiltration, or retention of nutrients. Thus, with increased grazing intensity, which reduces plant cover beyond a certain threshold, the feedbacks between plants and soil 'can create a stable, degraded bare state which cannot be reversed simply by reducing grazing pressure' (Augustine 2003:320). However, the opposite is also true under certain conditions; for example, on sodic sites, certain conditions give rise to highly productive grazing lawns that are dependent on high-intensity grazing for their formation and maintenance. These grazing lawns and/or other regularly utilised patches can be important for certain animal species (see Grant et al. 2019). The properties of soils on these nutrient hotspots and the processes of the catena could, however, also explain the bare soil areas, plant species composition and herbaceous plant density found in the sodic zone on the lower midslope (number 5, Figure 2).
Climate, especially temperature and moisture, has a direct impact on soil biochemical reactions (Whalen \& Sampedro 2010), such as mineralisation and/or accumulation of organic matter contents (carbon sequestration; Brady \& Weil 2002) (10, Figure 2). These reactions are largely driven by the microbial composition of the soil, which, in turn, is also directly influenced by the climate (11) (i.e. Classen et al. 2015) as well as the soil properties (12) and fire (Figure 1). The activity of fungi and bacteria would be impacted inter alia by the organic matter content, $\mathrm{pH}$ and the soil water content. The microbial abundance and activity would further be impacted by the plant community which provides specific conditions in the rhizosphere where certain microbial species can flourish (13).

Microbes, together with the vegetation in which root zones they occur, can be impacted by soil moisture and nitrogen availability. February and Higgins (2010) monitored soil moisture levels continuously at Satara and Pretoriuskop in KNP and found that surface layers are drier and on average exceed the wilting point for fewer days per year than the deeper layers. The negative correlation of root biomass with soil moisture is a representation of the dynamic process of removal of water through evaporation in upper soil layers and moisture that might actually be lower where highest root biomass and uptake capacity occur. They also reported a decrease in total soil nitrogen for the top $40 \mathrm{~cm}$ of the soil profile. Thus, the distribution of roots may primarily be responding to nitrogen availability and not necessarily to water availability (February \& Higgins 2010). According to Augustine (2003), lower water-holding capacity and decreased nitrogen in soil can increase the susceptibility of communities on the ridgetop or crest to grazing, and grazing intensity can vary with topography. This also seems to be consistent with larger aggregations of bare soil and annual plant communities at upper topographic positions, compared to lower positions (Augustine 2003). All these aspects are important to describe the presence of specific grass plants and their root zones, used in the study to indicate the bacteria associated with these rhizospheres (numbers 12 and 13, Figure 2).

Vernal pools and mud wallows are important components of the savanna ecosystem. A vernal pool is a seasonal, shallow, usually small, ephemeral water body, with no permanent inlet or outlet. Their occurrence and frequency of occurrence are directly determined by the precipitation (15, Figure 2). The high clay content of the soils (16) in combination with micro-topography and some of the geomorphological aspects determine their location on the catena (17). Various mammals also use some of these ephemeral water bodies for drinking and as mud wallows (18).

Climate (together with geology) is one of the main drivers of long-term vegetation patterns and processes in KNP (Scholtz et al. 2014). However, climate also affects vegetation response in the short term, as evidenced by the severe 2015-2016 drought experienced during our study period (see study area 
description) when one of the most severe droughts on record for the area in which the study site falls was experienced (Swemmer et al. 2018). Drought is not separately indicated, but included indirectly under the label 'Climate' on Figures 1 and 2. During October 2016, barely any herbaceous vegetation was visible on the catena as a result of drought (19, Figure 2) and was compounded by associated grazing pressure (i.e. Staver, Wigley-Coetsee \& Botha 2019). This specific drought affected various plant functional groups (Van Aardt et al. 2020), including forbs (Siebert, Klem \& Van Coller 2020), grasses (Janecke 2020; Wigley-Coetsee \& Staver 2020) and woody vegetation (Case et al. 2020; Swemmer 2020). The vegetation response during and after the drought was often dependent on past land use (Siebert et al. 2020) and/or catenal position (e.g. Swemmer 2020). Mammals are also influenced by climate (20, Figure 2 ) in terms of temperature (see, e.g. Shrestha et al. 2014), humidity and indirectly through rainfall that leads to vegetation growth (food for herbivores) and the presence of natural, surface drinking water. Although climate includes many other factors also, only temperature and rainfall have been included in the discussion. Many factors on the catena are impacted indirectly by the climate (Figure 1 and numbers 19 and 20 on Figure 2), by the veld condition and by the intensity and frequency of fire in the ecosystem.

The framework discussed in this section (Figures 1 and 2) highlighted the interconnectivity of a variety of abiotic and biotic components, and how this may have contributed towards shaping the heterogeneity in patterns and processes along our study catena. We acknowledge that there are numerous factors not mentioned here but that also form part of the processes, heterogeneity and functioning of savanna catena ecosystems, and these could be added in future efforts to refine the framework.

\section{Synthesis of research findings}

The focus of this section will be on providing a short, introductory synthesis of the findings published in the articles in this special issue that fits into the framework provided in the previous section. The catena in the study area consists of a low relief crest and upper midslope (slope $=1 \%$ ), sodic site, shrubveld inside a riparian area (footslope), a small floodplain area and drainage line. The geology,

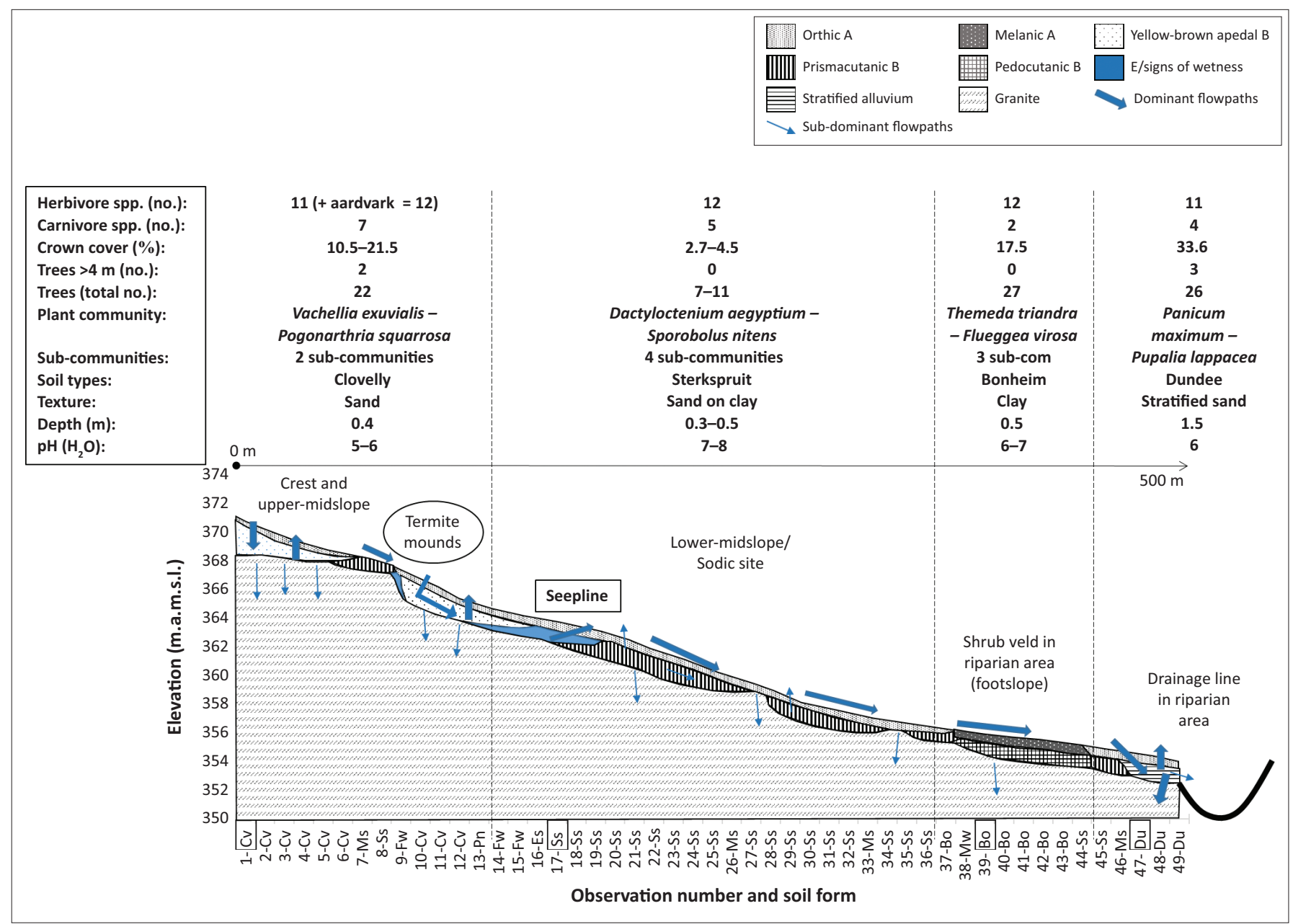

Soil forms or types: Cv, Clovelly; Ms, Mispah; Ss, Sterkspruit; Fw, Fernwood; Pn, Pinedine; Es, Estcourt; Bo, Bonheim; Mw, Milkwood; Du, Dundee.

FIGURE 3: Hydropedological response model, topography, soil types and properties, plant communities, vegetation structure (percentages and numbers of individual plants per $100 \mathrm{~m}$ transect) and number of mammal species in each zone on the catena. Numbers of mammals may seem similar between catenal zones, but do not necessarily fully overlap in species composition (Janecke \& Bolton 2020). The hydropedological response is described in detail in Bouwer et al. (2020) and Van Tol et al. (2020), soil forms (blocks indicate modal profiles where more detailed analyses were done) are described by Bouwer et al. (2020), the plant communities are described in Theron et al. (2020) and the vegetation structure is described in Janecke (2020). 
different soil types, some soil properties, the hydrology, vegetation communities, the number of trees and mammals are summarised in Figure 3.

\section{Hydrological processes}

Hydrological processes included all three catchment orders, with a focus on the third-order catena, whereupon it was shown that lateral interflow along the hillslope at the firstorder augment streamflows, whereas the second- and thirdorder stream reaches are conduits for groundwater recharge to the fractured rock aquifer and thereby show transmission loss from the stream network. Recharge soils are typical of the crests and footslopes through preferential vertical flow, whilst the midslope sodic regions are responsive in nature with strong lateral flow contributions at the surface and shallow sub-surface. Hillslope soil water balances revealed large variations in the riparian zones resulting from upslope contributions and evapotranspiration losses (Riddell et al. 2020).

\section{Soil distribution}

Four main soil forms were found from the crest to the valley bottom, namely, Clovelly, Sterkspruit, Bonheim and Dundee (Bouwer et al. 2020). The Clovelly soil dominates the crest position; this soil is relatively deep, sandy and freely drained, resulting in low inherent fertility and slightly acidic conditions. Below the Clovelly soil, a prominent seepline exists (Figure 3). This seepline marks the transition from crest to the midslope and the beginning of a sodic site. Sterkspruit soils dominate the sodic site with strong duplex character. There is an increase in clay, exchangeable cations (especially sodium [Na]) and $\mathrm{pH}$ on the sodic site when compared with the crest soils. These soils have a low hydraulic conductivity and will promote overlandflow (Van Tol et al. 2020). On the lower-midslope, Bonheim soils occur. Although they also have a relatively strong structure, there is a decline in the dominance of Na compared to other cations. In the valley bottom, Dundee soils formed from alluvial deposits dominate. These soils are coarse and freely drained with relatively low $\mathrm{pH}$ and nutrient status (Bouwer et al. 2020).

\section{Vegetation}

Differences between the four main soil types (chemical and physical properties) led to different vegetation communities and sub-communities that are associated with each soil type (Figure 3). Smaller differences between soil forms were also observed along the gradient as indicated in the plots where Mispah (Ms) (the Themeda triandra-Flueggea virosaSpirostachys africana sub-community in the riparian area occurs exclusively on this soil form [Theron et al. 2020]), Fernwood (Fw), Pinedine (Pn), Estcourt (Es) and Milkwood $(\mathrm{Mw})$ were found (Figure 3). Furthermore, the Themeda triandra-Flueggea virosa-Ehretia rigida sub-community on the midslope; the Dactyloctenium aegyptium-Sporobolus nitensBothriochloa radicans sub-community and the Dactyloctenium aegyptium-Sporobolus nitens-Aristida congesta sub-community of the riparian areas exclusively occur on Sterkspruit soils. The other sub-communities occur on a combination of different soil forms (Theron et al. 2020).

Differences in soil properties, moisture content, nutrients and the depth of the hard rock bed can all play a role in the number of trees (excluding other factors such as the impact of animals), especially large trees in different catenal zones. In the study area (Figure 3), most of the woody plants had canopy sizes less than $2 \mathrm{~m}$ wide, with a low number of big trees $(>5 \mathrm{~m}$ ) which occurred mostly on the banks of the drainage line and midslope (less than four big trees were found in a $100 \mathrm{~m} \times 3.5 \mathrm{~m}$ transect per zone). The canopy cover of woody plants ranged from $4 \%$ on the sodic site to $17 \%$ on the crest and midslope, and $33 \%$ in the riparian area at the drainage line (Janecke 2020). The soil type and depth present on the midslope, riparian shrubveld and drainage line banks (Figure 3) can support big trees, whilst possible access to ground water in the riparian zone might also explain their presence.

Just before the drought conditions peaked, the shrubveld inside the riparian area on the catena studied had a higher density of shrubs and of grass plants than the other vegetation zones (Janecke 2020, Theron et al. 2020). It might be that the shrubs created protected areas that led to increased grass densities, or that through the process of hydraulic lift more water was available closer to the soil surface, which enabled these shrubs and grasses to flourish. It may also be the fact that because of the denser woody conditions and associated reduction in visibility in the shrubveld, herbivores are avoiding those areas to reduce their predation risk (landscape of fear) and in this way grazing pressure was also reduced. Furthermore, the soil present in this zone is loamier and could, therefore, also hold more water. Bottomlands also have higher clay content, which is more nutrient rich and gives rise to higher productivity. These could be possible explanations for the presence of shrubs and a different herbaceous community than the rest of the catenal zones in the study area.

\section{Soil and plant associated microbes}

On a microscale the different ecotypes and soil conditions influence microbial communities in the rhizospheres of associated plants. Although the same plants may occur across vegetation zones, the microbes associated with the rhizospheres differ because of chemical differences (Vermeulen et al. 2020). Bacterial and fungal diversity of the rhizospheres of three species of herbaceous plants (Kyphocarpa angustifolia, Melhania acuminata and Sida cordifolia) growing mutually in two different soil types (Clovelly and Sterkspruit - Figure 3) of the catenal supersite was studied (Gryzenhout et al. 2020, Vermeulen et al. 2020). Carbon source utilisation patterns of bacteria in the rhizospheres of these plants were assessed in addition to Illumina sequencing of the 16s rRNA (V3 and V4 region), which was used to characterise the rhizobiome (Vermeulen et al. 2020). Principal component analysis (PCA) of Biolog data revealed no disparity between the five 
rhizobiomes based on carbon source utilisation of bacteria. Actinobacteria and Proteobacteria were the most dominant phyla in all rhizobiomes. Unique and shared operational taxonomic units were also identified in all the rhizobiomes (Vermeulen et al. 2020). Soil type and plant species play an important role in shaping the rhizosphere as unique operational taxonomic units were observed in all rhizospheres. For the fungi, differences between the two soil type rhizosphere communities were found, as well as for those within the roots (Gryzenhout et al. 2020).

\section{Mammals}

The vegetation creates habitat and provides food for herbivores. Available space for larger herds of herbivores and for larger sized mammals (mega-herbivores), as well as competition for food resources, predators, shelter and other factors, could influence animal densities in certain areas that can again affect their impact on vegetation and soil (Figure 1) (Janecke 2020). The total number of mammal species observed through camera trapping (herbivores + carnivores + other; Figure 3) in each catenal zone was as follows: crest and upper midslope (19 species), sodic patch (17 species), shrubveld (14 species), riparian area (15 species) and at the mud wallows (13 species). There were no obvious differences between mammal species observed in the different catenal zones. Common mammal species present on the catena, in order of frequency of observations, included impala, elephant, spotted hyena, kudu, giraffe, buffalo, zebra, warthog and grey duiker (Janecke and Bolton 2020). A total of 31 mammal species were observed on the catena over three camera trapping periods. Group sizes varied from a single individual to less than 10 individuals for most species, whilst for elephant it went up to 21 and for impala up to 90 individuals in a herd at certain times (Janecke \& Bolton 2020). The drought indirectly affected the presence or absence of mammal species and impacted on the numbers of the group or herd.

\section{Mud wallows and ephemeral pans}

In the study area, the temporary water-filled depressions (mud wallows and vernal pools) were found on the midslopesodic ecotone (close to the seepline) and next to the drainage line (Figure 3). This position is interpreted as being related to the wetter part of the hillslope. These vernal pools are important habitats not only for small aquatic organisms, such as Euphyllopod crustaceans (that formed part of this study), but also for other organisms. The drought is probably to blame for lack of crustaceans in these depressions at the time of study.

Various mammals used some of these temporal water bodies as mud wallows for thermal regulation, but it became especially heavily utilised during the intense heat of the extreme drought. The soils of the sodic site and riparian area have a higher clay content (Figure 3) with lower hydraulic conductivity, thus increasing its potential to retain water longer in holes created by animals than the more sandy soils of the midslope and crest. These depressions probably form because of the fact that water collects and remains for longer periods in these clayey soils, which then attracts the mammals to start wallowing in it. According to Janecke and Bolton (2020), these holes 'might fill up with rain water, surface runoff and there is a possibility that water seepage from underground may also play a role (depending on the position of the mud hole on the catena)' and based on the hydrology of the catena (Figure 3).

\section{Severe drought of 2015-2016}

As is common during drought periods, isolated small-scale rainfall events occurred during the drought and the study area seemingly received more rain during the study period than the surrounding landscapes, resulting in some grass plants retaining above-ground biomass and experiencing limited flushing, with trees retaining green leaves for longer. Anecdotal evidence during the study period suggested occurrence of some precipitation on the watershed between the Sabie and Crocodile River, where the supersite is situated, which is likely to have contributed to the seeming 'greenness' experienced. The veld in the study area appeared like a green island in the surrounding drought-stricken area during March 2016 and might have acted as an important critical resource area to sustain herbivores. The severity of the drought eventually took its toll on the vegetation and during October 2016, almost no herbaceous vegetation was observed, only bare soil (pers. obs. October 2016.). The presence of temporary surface water in holes created by large mammals was used for drinking and as mud wallows during 2015 and 2016 drought period (Janecke \& Bolton 2020) because it retained the rainwater for longer periods. This also contributed to sustaining mammals after water became scarce and is one of the reasons why certain mammal species were present in the study area.

Plant community and species composition changed in the crest and sodic site zones during the different sampling seasons as the drought progressed. These changes could not be seen in the richness and diversity of plants in these mentioned zones. Changes in the riparian areas were, however, not that clear and can be ascribed to the possible hydraulic lift from deeper soil layers, decreasing the impact of the drought (Van Aardt et al. 2020). The visible changes in the community compositions over the 2015-2018 period could possibly indicate that the granite catena is a relatively resilient ecosystem in terms of abiotic factors affecting the biotic factors.

\section{Future research}

This study provides baseline data and biotic-abiotic associations that can be built upon and the hypotheses presented by our conceptual framework can be further tested in future. Future research can inter alia focus on various other aspects, such as (1) comparing the geohydrology of a true wet, flowing catena to the dry and semi-dry catena that we experienced because of drought conditions; (2) determining the presence of animals over different seasons and over extended periods, including years with different rainfall regimes; (3) comparing the ecology, diversity and processes 
of other hillslopes in the supersite with our results, or (4) with other supersites which have different rainfall regimes and underlying geology; (5) including other animals (reptiles, birds, insects, invertebrates and other non-mammals) in the study and understanding how they may respond to catenal heterogeneity. LiDAR and/or terrestrial scanning of the study area is also a useful data set to acquire for the study area in future. According to Naiman et al. (2003), it must be kept in mind that the environment system is complex and full of non-linearity, amplifications, thresholds, damping effects and more that make prediction difficult. However, the formulation of the general principles is not impossible; it just poses a major challenge that ecologists must accomplish.

\section{Conclusion}

Biodiversity and heterogeneity associated with the catena ecosystem processes are important components in understanding the dynamics of the savanna ecosystem as a whole. Most research projects focus on only one or a few of the biotic and abiotic components, and possibly one or two connections between these components, but studies considering a multitude of biotic and abiotic components and their interaction, feedback and integration are rare. This research aimed to contribute towards the knowledge gap by studying the biotic and abiotic components during the same period and in the same local area, to make the interactions, relationships and processes of the ecosystem more explicit and, hence, providing a systemic conceptual understanding of the patterns and connections within the study system. To better understand the complexity of these ecosystems, there will always be opportunity for research to gain more knowledge and a better understanding of these unique ecosystems.

Furthermore, we trust that this article, and all the studies forming part of the special issue, will contribute valuable baseline information and provide a useful first stab at a conceptual understanding of the patterns, processes and interactions on the KNP Southern Granite Supersite. We envisage that this will stimulate further research on the supersites to become pivotal research sites for multidisciplinary studies of savanna ecosystems.

\section{Acknowledgements}

The authors would like to acknowledge the University of the Free State (UFS) Strategic Research Fund for funding the multidisciplinary research; SANParks Scientific Services and game guards for their friendly assistance; Dr Marcele Vermeulen from Microbial, Biochemical, and Food Biotechnology (UFS) for her contributions to the article; and the late Dr Fred Kruger (OTS \& UFS) who was very enthusiastic and excited about this multidisciplinary project but passed away in 2017 before the publication of the special issue.

\section{Competing interests}

The authors declare that they have no financial or personal relationships that may have inappropriately influenced them in writing this article.

\section{Authors' contributions}

All authors directly participated in the study design and interpretation of the multidisciplinary research. The first three authors wrote the main part of the article, whilst B.B.J. and J.v.T. also created the figures with some input from the entire team. The other authors contributed mostly to their expert research field in the article. P.A.L.l.R. is acknowledged for the vision and concept of this research project. M.T.S. and A.C.v.A assisted with language editing.

\section{Ethical considerations}

Ethical approval for the multidisciplinary project as a whole was obtained from the Interfaculty Animal Ethics Committee at the University of the Free State (UFSAED2019/0121). Declaration: For project number LROPAL1255 (LROPAL1345 extension addendum) as on the contract between the principal investigator and SANParks Scientific Services, the following permits were issued to collect and remove soil samples for laboratory analyses, vegetation samples for identification purposes, mud samples to identify small aquatic organisms and soil samples from rhizospheres for microbe analyses: SK069; SK2095; SK054.

\section{Funding information}

The authors are grateful to the University of the Free State (UFS) Strategic Research Fund for largely funding this multidisciplinary research.

\section{Data availability}

Data sharing is not applicable to this article as no new data were created or analysed during this study.

\section{Disclaimer}

The views and opinions expressed in this article are the authors' own and not an official position of the institution or funder.

\section{References}

Adler, P.B., Raff, D.A. \& Lauenroth, W.K., 2001, 'The effect of grazing on the spatial heterogeneity of vegetation', Oecologia 128, 465-479. https://doi.org/10.1007/ s004420100737

Asner, G.P. \& Levick, S.R., 2012, 'Landscape-scale effects of herbivores on treefall in African savannas', Ecology letters 15(11), 1211-1217. https://doi.org/10.1111/ j.1461-0248.2012.01842.x

Asner, G.P., Vaughn, N., Smit, I.P.J. \& Levick, S., 2016, 'Ecosystem-scale effects of megafauna in African savannas', Ecography 39(2), 240-252. https://doi.org/10.1111/ ecog.01640

Augustine, D.J., 2003, 'Spatial heterogeneity in the herbaceous layer of a semi-arid savanna ecosystem', Plant Ecology 167, 319-332. https://doi.org/10.1023/ A: 1023927512590

Bouwer, D., Le Roux, P.A.L. \& Van Tol, J., 2020, 'Identification of hydropedological flowpaths in Stevenson-Hamilton catena from soil morphological, chemical and hydraulic properties', Koedoe 62(2), a1584. https://doi.org/10.4102/koedoe. v62i2.1584

Brady, N.C. \& Weil, R.R., 2002, The nature and properties of soils, 13th edn., Prentice Hall, NJ.

Burkepile, D.E., Burns, C.E., Tambling, C.J., Amendola, E., Buis, G.M., Govender, N. et al., 2013, 'Habitat selection by large herbivores in a southern African savanna: The relative roles of bottom-up and top-down forces', Ecosphere 4(11), 1-19. https://doi.org/10.1890/ES13-00078.1 
Case, M.F., Wigley, B.J., Wigley-Coetsee, C. \& Carla Staver, A., 2020, 'Could drought constrain woody encroachers in savannas?' African Journal of Range \& Forage constrain woody encroachers in savannas?' African Journal of Range \&
Science 37(1), 19-29. https://doi.org/10.2989/10220119.2019.1697363

Classen, A.T., Sundqvist, M.K., Henning, J.A., Newman, G.S., Moore, J.A.M., Cregger, M.A. et al., 2015, 'Direct and indirect effects of climate change on soil microbial and soil microbial-plant interactions: What lies ahead?', Ecosphere 6(8), 1-21. https://doi.org/10.1890/ES15-00217.1

Du Toit, J.T., Rogers, K.H. \& Biggs, H.C. (eds.), 2003, The Kruger experience: Ecology and management of savanna heterogeneity, Island Press, Washington, DC.

Eckhardt, H.C., Van Wilgen, B.W. \& Biggs, H.C., 2000, 'Trends in woody vegetation cover in the Kruger National Park, South Africa, between 1940 and 1988', African Journal of Ecology 38(2), 108-115. https://doi.org/10.1046/j.1365-2028.2000.00217.x

February, E.C. \& Higgins, S.I., 2010, 'The distribution of tree and grass roots in savannas in relation to soil nitrogen and water', South African Journal of Botany 76(3), 517-523. https://doi.org/10.1016/j.sajb.2010.04.001

Grant, C.C., Botha, J., Grant, T.C., Peel, M.J.S. \& Smit, I.P.J., 2019. 'When less is more: heterogeneity in grass patch height supports herbivores in counter-intuitive ways', African Journal of Range \& Forage Science 36(1), 1-8. https://doi.org/10.2989/10 220119.2018.1543209

Gryzenhout, M., Cason, E.D., Vermeulen, M., Kloppers, G.A.E., Bailey, B. \& Ghosh, S. 2020 , 'Fungal community structure variability between the root rhizosphere and endosphere in a granite catena system in the Kruger National Park, South Africa', Koedoe 62(2), a1597. https://doi.org/10.4102/koedoe.v62i2.1597

Hempson, G.P., Archibald, S., Bond, W.J., Ellis, R.P., Grant, C.C., Kruger, F.J. et al., 2015, 'Ecology of grazing lawns in Africa', Biological Reviews 90(3), 979-994. https://doi. org/10.1111/brv.12145

Hu, S. \& Fedorov, A.V., 2017, 'The extreme El Niño of 2015-2016: The role of westerly and easterly wind bursts, and preconditioning by the failed 2014 event', Climate Dynamics 48, 1-19. https://doi.org/10.1007/s00382-017-3531-2

Janecke, B.B., 2020, 'Vegetation structure and spatial heterogeneity in the Granite Supersite, Kruger National Park', Koedoe 62(2), a1591. https://doi.org/10.4102/ koedoe.v62i2.1591

Janecke, B.B. \& Bolton, J., 2020, 'Variation in mammal diversity and habitat affect heterogeneity and processes of a granite catena', Koedoe 62(2), a1592. https:// doi.org/10.4102/ koedoe.v62i2.1592

Khomo, L.M., Hartshorn, A.S., Rogers, K.H. \& Chadwick, O.A., 2011, 'Impact of rainfall and topography on the distribution of clays and major cations in granitic catenas of southern Africa', Catena 87(1), 119-128. https://doi.org/10.1016/j.catena.2011.05.017

Khomo, L.M. \& Rogers, K.H., 2005, 'Proposed mechanism for the origin of sodic patches in Kruger National Park, South Africa', African Journal of Ecology 43(1) patches in Kruger National Park, South Africa', African Jou
29-34. https://doi.org/10.1111/j.1365-2028.2004.00532.x

Laundre, J.W., Hernandez, L. \& Ripple, W.J., 2010, 'The landscape of fear: Ecological implications of being afraid', The Open Ecology Journal 3(3), 1-7. https://doi. org/10.2174/1874213001003030001

Le Roux, E., Kerley, G.I.J. \& Cromsigt, J.P.G.M., 2018, 'Megaherbivores modify trophic cascades triggered by fear of predation in an African savanna ecosystem', Current Biology 28(15), 2493-2499. https://doi.org/10.1016/j.cub.2018.05.088

Malherbe, J., Smit, I.P.J., Wessels, K.J. \& Beukes, P.J., 2020, 'Recent droughts in the Kruge National Park as reflected in the extreme climate index', African Journal of Range \& Forage Science 37(1), 1-17. https://doi.org/10.2989/10220119.2020.1718755

McNaughton, S.J. 1983, 'Compensatory plant growth as a response to herbivory', Oikos 40(3), 329-336. https://doi.org/10.2307/3544305

Milewski, A.V. \& Madden, D. 2006, 'Interactions between large African browsers and thorny Acacia on a wildlife ranch in Kenya', African Journal of Ecology 44(4), 515-522. https://doi.org/10.1111/j.1365-2028.2006.00665.x

Milne, G., 1936, 'A provisional soil map of East Africa', Geograf Review 26(3), 522-523. https://doi.org/10.2307/209064

Naiman, R.J., Braack, L., Grant, R., Kemp, A.C., Du Toit, J.T. \& Venter, F., 2003, 'Interactions between species and ecosystem characteristics', in J.T. du Toit, K.H. Rogers \& H.C. Biggs (eds.), The Kruger experience: Ecology and management of Savanna heterogeneity, pp. 221-241, Island Press, Washington, DC.

Nasar, J.L. \& Jones, K.M., 1997, 'Landscapes of fear and stress', Environment and Behavior 29(3), 291-323. https://doi.org/10.1177/001391659702900301

Pickett, S.T.A., Cadenasso, M.L. \& Benning, T.L., 2003, 'Biotic and abiotic variability as key determinants of savanna heterogeneity at multiple spatiotemporal scales', in J.T. du Toit, K.H. Rogers \& H.C. Biggs (eds.), The Kruger experience: Ecology and management of Savanna heterogeneity, pp. 22-40, Island Press, Washington, DC.

Riddell, E.S., Nel, J., Fundisi, D., Jumbi, F., Van Niekerk, A. \& Lorentz, S., 2014, Ephemeral hydrological processes in savannas, WRC report No. TT619/14, Water Research Commission, Pretoria.

Riddell, E.S., Nel, J.M., Van Tol, J., Fundisi, D., Jumbi, F., Van Niekerk, A. et al., 2020 'Groundwater-surface water interactions in an ephemeral savanna catchment, Kruger National Park', Koedoe 62(2), a1583. https://doi.org/10.4102/koedoe v62i 2.1583

Rietkerk, M., Ketner, P., Burger, J., Hoorens, B. \& Olff, H., 2000, 'Multiscale soil and vegetation patchiness along a gradient of herbivore impact in a semi-arid grazing system in West Africa', Plant Ecology 148, 207-224. https://doi.org/10.1023/ A:1009828432690
Rietkerk, M., Van den Bosch, F. \& Van de Koppel, J., 1997, 'Sitespecific properties and irreversible vegetation changes in semiarid grazing systems', Oikos 80(2), 241-252. https://doi.org/10.2307/3546592

Rogers, K.H., 2003, 'Adopting a heterogeneity paradigm: Implications for management of protected savannas', in J.T. du Toit, K.H. Rogers \& H.C. Biggs (eds.), The Kruger experience - Ecology and management of savanna heterogeneity, pp. 41-58, Island Press, Washington, DC.

Sankaran, M., Hanan, N.P., Scholes, R.J., Ratnam, J., Augustine, D.J., Cade, B.S. et al., 2005, 'Determinants of woody cover in African savannas', Nature 438(7069), 846. https://doi.org/10.1038/nature04070

Scholtz, R., Kiker, G.A., Smit, I.P.J. \& Venter, F.J., 2014, 'Identifying drivers that influence the spatial distribution of woody vegetation in Kruger National Park, South Africa', Ecosphere 5(6), 1-12. https://doi.org/10.1890/ES14-00034.1

Siebert, F. \& Eckhardt, H.C., 2008, 'The vegetation and floristics of the Nkuhlu Exclosures, Kruger National Park', Koedoe 50(1), 126-144. https://doi.org/10.4102/ koedoe.v50i1.138

Siebert, F., Klem, J. \& Van Coller, H., 2020, 'Forb community responses to an extensive drought in two contrasting land-use types of a semi-arid Lowveld savanna', African Journal of Range \& Forage Science 37(1), 53-64. https://doi.org/10.2989/ 10220119.2020.1726464

Shrestha, A.K., Van Wieren, S.E., Van Langevelde, F., Fuller, A., Hetem, R.S., Meyer, L. et al., 2014, 'Larger antelopes are sensitive to heat stress throughout all seasons but smaller antelopes only during summer in an African semi-arid environment', International Journal of Biometeorology 58(1), 41-49. https://doi.org/10.1007/ s00484-012-0622-y

Smit, I.P.J., 2020, 'Integrating multi-scaled and multi-disciplinary studies: A critical reflection on the Kruger National Park Research Supersites', Koedoe 62(2), a1586. https://doi.org/10.4102/koedoe.v62i2.1586

Smit, I.P.J. \& Bond, W.J., 2020, 'Observations on the natural history of a savanna drought', African Journal of Range \& Forage Science 37(1), 119-136. https://doi. org/10.2989/10220119.2020.1723695

Smit, I.P.J. \& Prins, H.H.T., 2015, 'Predicting the effects of woody encroachment on mammal communities, grazing biomass and fire frequency in African savannas', PLoS One 10(9), e0137857. https://doi.org/10.1371/journal.pone.0137857

Smit, I.P.J., Riddell, E.S., Cullum, C. \& Petersen, R., 2013, 'Kruger National Park research supersites: Establishing long-term research sites for cross-disciplinary, multiscaled learning', Koedoe 55(1), Art\#1107, 7 pages. https://doi.org/10.4102/koedoe. v55i1.1107

Staver, A.C., Wigley-Coetsee, C. \& Botha, J., 2019, 'Grazer movements exacerbate grass declines during drought in an African savanna', Journal of Ecology 107(3), 1482-1491. https://doi.org/10.1111/1365-2745.13106

Swemmer, A.M., 2020, 'Locally high, but regionally low: the impact of the 2014-2016 drought on the trees of semi-arid savannas, South Africa', African Journal of Range \& Forage Science 37(1), 31-42. https://doi.org/10.2989/10220119.2020.1723696

Swemmer, A.M., Bond, W.J., Donaldson, J., Hempson, G.P., Malherbe, J. \& Smit, I.P.J., 2018, 'The ecology of drought - a workshop report', South African Journal of Science 114(9-10), 1-3. https://doi.org/10.17159/sajs.2018/5098

Theron, E., Van Aardt, A.C. \& Du Preez, P.J., 2020, 'Vegetation distribution along a granite catena, southern Kruger National Park, South Africa', Koedoe 62(2), a1588. https://doi.org/10.4102/koedoe.v62i2.1588

Treydte, A.C., Van der Beek, J.G.M., Perdok, A.A. \& Van Wieren, S.E., 2011, 'Grazing ungulates select for grasses growing beneath trees in African savannas', Mammalian Biology 76(3), 345-350. https://doi.org/10.1016/j.mambio.2010.09.003

Trollope, W.S.W., Trollope, L.A., Biggs, H.C., Pienaar, D. \& Potgieter, A.L.F., 1988, 'Longterm changes in the woody vegetation of the Kruger National Park with special reference to the effects of elephants and fire', Koedoe 41(2), 103-112. https://doi. org/10.4102/koedoe.v41i2.255

Van Aardt, A.C., Codron, D., Theron, E. \& Du Preez, P.J., 2020, 'Plant community structure and possible vegetation changes after drought on a granite catena in the Kruger National Park, South Africa', Koedoe 62(2), a1585. https://doi.org/10.4102/ koedoe.v62i2.1585

Van Tol, J., Julich, S., Bouwer, D. \& Riddell, E.S., 2020, 'Hydrological response in a savanna hillslope under different rainfall regimes', Koedoe 62(2), a1602. https:// doi.org/10.4102/koedoe.v62i2.1602

Vermeulen, M., Cason, E.D. \& Swart, W.J., 2020, 'The rhizobiome of herbaceous plants in Clovelly and Sterkspruit soils of the Stevenson-Hamilton supersite', Koedoe 62(2), a1596. https://doi.org/10.4102/koedoe.v62i2.1596

Whalen, J.K \& Sampedro, L, 2010, Soil ecology and management, Cambridge University Press, Cambridge.

Whyte, I.J., Van Aarde, R.J. \& Pimm, S.L., 2003, 'Kruger's elephant population: Its size and consequences for ecosystem heterogeneity', in J.T. du Toit, K.H. Rogers \& H.C. Biggs (eds.), The Kruger experience - Ecology and management of savanna heterogeneity, pp. 332-348, Island Press, Washington, DC.

Wigley-Coetsee, C. \& Staver, A.C., 2020, 'Grass community responses to drought in an African savanna', African Journal of Range \& Forage Science 37(1), 43-52. https:// doi.org/10.2989/10220119.2020.1716072 